\title{
A ARTICULAÇÃO DO PASSADO E A CHAVE ÉTICA DO TESTEMUNHO EM CADERNO DE MEMÓRIAS COLONIAIS, DE ISABELA FIGUEIREDO
}

\author{
THE ARTICULATION OF THE PAST AND THE \\ ETHICAL KEY OF TESTIMONY IN \\ "CADERNO DE MEMÓRIAS COLONIAIS", \\ BY ISABELA FIGUEIREDO
}

Rodrigo Cavelagna ${ }^{1}$

\begin{abstract}
RESUMO
Caderno de memórias coloniais, de Isabela Figueiredo (2018), constitui-se como uma escrita de memórias, no qual uma narradora-personagem rememora sua infância, abrangendo o período da Guerra de Independência de Moçambique (1964-1974) e, posteriormente, o processo de mudança social e política que se dá em Portugal após o 25 de abril de 1974. O livro representa a opressão do regime colonial e a denúncia de suas violências, valendo-se de diversos recursos estéticos, com uma composição fragmentária que traduz a complexidade do testemunho inscrito. Neste artigo, nos deteremos nas reflexões sobre a memória, na retomada de temas de Levi (2016), e na elaboração do testemunho, a partir da postura ética-política que assume a narradora-personagem. Para essa discussão empenhamos crítica específica, em Silvio Renato Jorge (2015) e Daniel Laks (2019), e bibliografia geral, em Walter Benjamin (2012), Márcio Seligmann-Silva (2008) e Jeanne Marie Gagnebin (2009).
\end{abstract}

PALAVRAS-CHAVE: Memória. Testemunho. Ética. Isabela Figueiredo. 


\section{ABSTRACT}

Caderno de memórias coloniais, by Isabela Figueiredo (2018), is composed of a memoirist writing, in which a narrator-character remembers her childhood, covering the period of the Mozambican War of Independence (1964-1974) and, subsequently, the process of social and political change that takes place in Portugal after April 25, 1974. The book represents the oppression of the colonial regime and the denunciation of its violence, using various aesthetic resources, with a fragmentary composition that translates the complexity of the inscribed testimony. In this article, we will focus in the reflections on memory, on the resumption of themes by Levi (2016), and in the elaboration of the testimony, from the ethical-political posture assumed by the narrator-character.For this discussion, we will use specific analyses, in Silvio Jorge (2015) and Daniel Laks (2019), and general bibliography, in Walter Benjamin (2012), Márcio Seligman-Silva (2008) and Jeanne Marie Gagnebin (2009).

KEYWORDS: Memory. Testimony. Ethic. Isabela Figueiredo.

\section{INTRODUÇÃO}

Caderno de Memórias Coloniais, de Isabela Figueiredo² (2018), apresenta ao leitor uma série de fragmentos de memórias, revisitados por uma narradora-personagem que rememora sua infância, desde seu nascimento em 1963, durante as décadas de 60 e 70 em Lourenço Marques, hoje Maputo, capital de Moçambique. De seu relacionamento com o pai, de seu aprendizado e gosto pela leitura, de seus primeiros sentimentos amorosos, até as violências sofridas e infligidas. E sua ida, sozinha, à Portugal, após o 25 de abril, a vida como "retornada" em um país em que nunca estivera. Neste livro, Figueiredo nos oferece seu testemunho com grande sensibilidade estética, cenas do cotidiano de uma criança em um momento de grande opressão, imersa em seus paradoxos. Questiona, de modo irônico, a hipocrisia do sistema opressivo, escancarando sua brutalidade. Descreve a forte relação com o pai, figura que representa todo o amor filial e, paradoxalmente, força de emancipação, suporte terreno, mas que também é a face do patriarcado e do machismo - é o próprio colonizador.

A narrativa abrange o período da Guerra de Independência de Moçambique (1964-1974) e, posteriormente, o processo de mudança social e política que se dá em Portugal após o 25 de abril de 1974. Assim, todos os acontecimentos do livro estão envoltos pelas violências do processo colonial: o racismo é escancarado ao leitor, em suas formas sistemáticas de opressão pelo Estado, e da violência estruturante da colônia, mas também aquele que é germe, íntimo, manifestado em ações cotidianas e que se mantém na sociedade mesmo após revoluções. O tratamento dos temas é direto: 
Uma branca não admitia que gostasse de foder, mesmo que gostasse. E não admitir era uma garantia de seriedade para o marido, para a imaculada sociedade toda. As negras fodiam, essas sim, com todos e mais alguns, com os negros e os maridos das brancas, por gorjeta, certamente, por comida ou por medo. $\mathrm{E}$ algumas talvez gostassem, e guinchassem, porque as negras era animais e podiam guinchar. (FIGUEIREDO, 2018, p. 40)

Essa crueza no uso das palavras, que se apoia na revisão irônica pelo distanciamento temporal da narradora e na assimilação do discurso do mito civilizatório para compor um efeito crítico, é chave importante para a própria constituição estética e temática da narrativa. Isto é, mostra-se de modo claro ao leitor como se dá a violência racial no cotidiano da colônia, no próprio âmbito de elaboração da linguagem. Além disso, o livro é permeado por fotos, recortes de momentos, analisados por Silvio Renato Jorge (2015), que observa suas singularidades de leitura e o modo como elas se inter-relacionam na composição geral. Reafirmando os procedimentos centrais, o crítico salienta que

o Caderno apresenta duas características muito marcantes, que eu não poderia deixar de destacar. A primeira delas é o fato de recuperar cenas, imagens, resquícios de características do fato colonial que são destacadas em boa parte das reflexões teóricas sobre o tema: fala-se de sexualidade, de racismo, do mito civilizatório. A segunda é a presença vigorosa de um eu discursivo que reconhece sua inevitável parcela de responsabilidade nesse processo, ainda que involuntária, e não se permite a omissão da violência intrínseca ao fato (JORGE, 2015, p. 56)

Daniel Laks (2019), por sua vez, ao retomar o capítulo "O Post-Modernismo e a Ficção Portuguesa do Fim do Século”, de Carlos Reis (2005), destaca que o "Caderno de Memórias Coloniais apresenta todas as linhas de força que Reis caracterizou como definidoras da ficção portuguesa contemporânea" (LAKS, 2019, p. 65): o uso da História como suporte para a narrativa; a constituição do narrador como um ser estilhaçado, com um conhecimento fragmentado de si; a reinterpretação da cultura ocidental, de seus episódios e figuras mitificadas; os processos de incorporação, na narrativa, de elementos autobiográficos e de outros textos. E salienta que

a literatura portuguesa, à qual a narrativa em questão se filia, toma para si a reponsabilidade de rever ficcionalmente o processo de descolonização, o redesenho das fronteiras nacionais, os dramas individuais e coletivos da guerra colonial e as consequências identitárias de tais processos. (LAKS, 2019, p. 35)

$\mathrm{Na}$ esteira desses críticos, nos deteremos nas imagens de violência e na constituição da memória dos horrores do processo colonial. Interessa observar como Figueiredo assume uma postura ética-política na articulação da memória de infância e de seu testemunho: há uma singularidade em sua posição que pode desvelar múltiplos fatores que envolvem essa experiência o que se desdobra em reflexão metaliterária e em soluções estéticas diversas. 
Na primeira parte deste artigo, portanto, exploramos a articulação ética da memória do colonialismo, a partir de uma das epígrafes do livro e de sua composição interna. Na segunda, observando o paralelo com a personagem do primo, percorremos as singularidades do testemunho, e do trauma, que Isabela Figueiredo elabora.

\section{A ARTICULAÇÃO DA MEMÓRIA E A CONSTITUIÇÃO DA IDENTIDADE}

Uma das epígrafes de Caderno de memórias coloniais é retirada do início de Os afogados e os sobreviventes (2016), de Primo Levi:

A memória humana é um instrumento maravilhoso, mas falível.

$[\ldots]$

As recordações que jazem dentro de nós não são gravadas em pedra; têm não só a tendência para se apagarem com os anos, como também é frequente modificarem-se, ou inclusivamente aumentarem, incorporando delineamentos estranhos. (FIGUEIREDO, 2018, p. 28)

Trata de um ponto central em diversas reflexões sobre a memória: seu caráter moldável, permeável de restos, resquícios. Rastros, alguns que nem são totalmente visíveis ou mesmo que parecem não importar, mas que estão presentes. Levi (2016, p. 17), prosseguindo nessa reflexão, discorre sobre o inevitável e até certo ponto natural ofuscamento das memórias, todas, que caem no esquecimento com o passar dos anos. E se detém, propriamente, na elaboração da memória de experiências traumáticas, na qual "atuam todos ou quase todos os fatores que podem obliterar ou deformar o registro mnemônico" (LEVI, 2016, p.18): os próprios traumas, físicos e mentais, que retornam em violência na rememoração; os recalques e repressões, decorrentes das tentativas de justificação ou esquecimento; as interferências de recordações similares e concorrentes sobre um mesmo episódio.

A epígrafe, desse modo, funciona não só como tema, mas como reflexão teórica, que encontra soluções diversas na escrita da Figueiredo, até mesmo na construção de detalhes e de coisas pequenas, aparentemente sem importância: "Em novembro, fazia muito calor e eu usava um vestido branco em tecido crepe. Não podia me sujar. Tudo isto parecia certo, mas é mentira. Eu me vestia de azul." (FIGUEIREDO, 2018, p. 125). Mas, principalmente, naquilo que se desdobra em memória coletiva, como o 25 de abril de 1974, no qual concorrem diferentes versões:

Qual dos cenários é o real? A conversa sobre o 25 de abril teve lugar lá em cima, no Alto-Maé, ou na Baixa? Foi a mesma conversa? Foram conversas diferentes sobre o mesmo assunto? Prefiro o segundo cenário. Talvez as duas tenham acontecido. A coerência do tempo e do espaço, a uma grande distância, perde-se. "Foi assim”, "tenha cá esta ideia”. Uma coisa é certa: aconteceu. (FIGUEIREDO, 2018, p. 95) 
A memória passa por um processo de seleção, uma "preferência" aos acontecimentos. Há uma seletividade, não aleatória, das diferentes versões do passado, tanto no âmbito individual quanto no coletivo e isso está na própria constituição do livro. Elabora-se uma narradora-personagem situada em um presente que lhe permite rememorar de modo crítico sua infância. Note-se que essas memórias não são apenas as de sua vida em Moçambique durante o regime colonial, mas também as do primeiro período de sua vida em Portugal. Essa escolha já demonstra como o regime se estende para a chamada "metrópole", não restrito ao país oprimido, e nos sugere já no título as configurações de sua vivência como retornada.

Nesse sentido, é importante observar como se dá a construção de identidade da personagem. Daniel Laks (2019) demonstra como ela se constitui em uma dupla noção, que dá contornos tanto de um desejo de pertencimento à comunidade quanto de uma "traição ao pai", um dos motes do livro ${ }^{3}$, ao negar-se a assumir ou deixar-se guiar por ideários chamados “imutáveis”. Em Laks:

A noção de identificação grupal aparece estabelecida no ideário das pessoas como um dado imutável: "Ou se era colono ou se era colonizado, não se podia ser qualquer coisa de transição, sem um preço, a loucura no horizonte" (Figueiredo, 2015, p. 157). De forma análoga, a identificação familiar também é estabelecida com um dado fechado, onde a narradora é descrita como sendo a filha de seu pai e, dessa forma, indissociável de suas condutas: "O branco foi lá dentro, deu porrada no Ernesto, agora vai a sair, o branco trouxe a menina, é a filha do branco" (Figueiredo, 2015, p. 92). Entretanto, a construção da identidade da narradora se faz especificamente a partir da negação da figura do pai e das regras do grupo: "Uma branca não vendia mangas no chão, à porta. Mas eu era uma colonazinha preta, filha de brancos. Uma negrinha loira. E a colonazinha negra que eu era vendia montezinhos de mangas do lado de fora do portão da machamba" (Figueiredo, 2015, p. 69). É o desejo pelo diferente enquanto formador da identidade da narradora e, desse modo, a oposição entre as ideias dela e as de seus pais e pares que impulsiona a narrativa e expõe as marcas do racismo e do machismo colonialista, principalmente a partir da representação da figura paterna. (LAKS, 2019, p. 69)

Para o escopo deste artigo, destaca-se que é uma identidade que se constrói criticamente, na aproximação com o diferente (a cultura negra, ainda que como invasora) e no confronto com o dito imutável (figurado no pai e no regime). Na elaboração do livro como um todo, portanto, a sequência de fragmentos de memória que compõem a narrativa corresponde à própria constituição da narradora-personagem, que é composta por recortes de diferentes matizes. 
Em outro tratamento, podemos observar como as reflexões sobre a indefinição e seletividade da memória perpassam procedimentos estéticos no livro. No fragmento 7 há a rememoração de uma foto, dos acontecimentos do dia em que ela foi tirada, "na machamba do [não se percebia o nome] num domingo em que se matou um cabrito" (FIGUEIREDO, 2018, p. 54). O jogo da ficcionalização autobiográfica fica mais intenso: a narradora-personagem cita coisas supostamente escritas no verso da fotografia, que se mesclam com as lembranças do dia. Na página anterior, está inserida uma foto. Fragmento e foto se misturam, como se fosse uma descrição. Mas a aproximação não é completa, a memória elaborada é diferente de uma descrição direta da foto - que por sua vez pode ser de qualquer outra situação. Mas parece importar menos para a constituição de Caderno de Memória Coloniais se a foto é ou não aquela, isto é, a não correspondência imediata é mais importante. Isso se acentua no parágrafo seguinte: "Li sua caligrafia perfeita, clara, legível” (FIGUEIREDO, 2018, p. 54) - o que entra em tensão com o uso de colchetes, como um jogo com o leitor. Abre-se, desse modo, à narração não um domingo específico, o da foto, mas um qualquer, como todos os outros. "Reconstruo esta foto a partir do total vazio de memória" (FIGUEIREDO, 2018, p. 56).

Essas tensões parecem indicar como se dá a articulação dos fragmentos no processo de rememoração. Aqui transitamos da elaboração pessoal da memória de infância para a relação desta com os acontecimentos históricos. Com o que chamamos "passado". Assim, a própria recuperação dessas memórias se constitui como uma ação ativa, que indica um forte posicionamento crítico, contrário à opressão do regime colonial.

Nas teses "Sobre o conceito de história", Walter Benjamin diz que "articular historicamente o passado não significa conhece-lo 'tal como ele de fato foi'. Significa apropriar-se de uma recordação, tal como ela relampeja no momento de um perigo" (BENJAMIN, 2012, p. 243). Há muito das teses como um todo nesse trecho. Compreender o passado como uma sequência de eventos, com suposto distanciamento, seria realizar a busca por uma "verdade eterna" que será sempre a dos "vencedores". Isso culmina em sua tese sobre a necessidade de "escovar a história a contrapelo" (BENJAMIN, 2012, p. 245), isto é, a rememoração e reescrita da história pela ótica das vítimas. Cada fragmento de memória é também uma centelha de esperança, que jaz na tradição dos oprimidos. Jeanne Marie Gagnebin, ao retomar essa mesma citação, ressalta que "nós articulamos o passado, diz Benjamin, nós não o descrevemos" (GAGNEBIN, 2009, p. 39). O passado não pode ser descrito, como se fosse um objeto, por sua própria condição. Se o passado, desse modo, é uma construção, "sob a aparência da exatidão científica (que é preciso examinar com circunspecção), delineia-se uma história, uma narração que obedece a interesses precisos." (GAGNEBIN, 2009, p. 40). Gagnebin salienta ainda que "a verdade do passado remete mais a uma ética da ação presente que a uma problemática da adequação (pretensamente científica) entre 'palavras' e 'fatos'” (GAGNEBIN, 2009, p. 39). Isto é, articular o passado em favor dos oprimidos é uma ação ética que transforma o presente. 
Em Caderno de memórias coloniais há um constante esforço contra o esquecimento. ${ }^{4}$ Isso se deixa perceber nas diversas reflexões críticas da narradora, ao longo da recuperação dos fragmentos, e nos momentos em que a narrativa se desvela em denunciar o sistema colonial, de como se estrutura o racismo no cotidiano e se manifesta nos direitos. Mas é importante considerar que essa tomada de consciência e de posicionamento ético da narradora-personagem, ao articular o passado, desenvolve-se com seus questionamentos internos, ao longo da narrativa, de sua vida, como podemos observar em alguns trechos:

Os criados eram pretos e nós deixávamos-lhes gorjeta se tivessem mostrado os dentes, sido rápidos no serviço e chamado patrão. Digo nós, porque eu estava lá. Nenhum branco gostava de ser servido por outro branco, até porque ambos antecipavam maior gorjeta. (FIGUEIREDO, 2018, p. 42)

“Digo nós, porque eu estava lá". Estamos no fragmento 4, em que são descritas algumas das relações de poder. Figueiredo não nega a inserção da narradora-personagem, a sua própria, nesse sistema. Prossegue, algumas páginas à frente: "um preto dedicado, fiel, que tirasse o boné, dobrasse a espinha à nossa passagem" (FIGUEIREDO, 2018, p. 45 - grifo do autor). Apesar de sua constituição identitária se dar nesse espaço de "transição", deixa-se bem claro que há uma tremenda cisão política e social entre "nós" e "eles" - fratura que lhe será interna, como retornada. Há, inclusive, já no fragmento 16, uma reflexão sobre como o racismo sistemático se engendra, como essa violência é reproduzida. O trecho rememora vez em que ela agride outra criança:

Foi premeditado. Tinha pensado antes, se ela voltar a irritar-me, bato-lhe. Podia perfeita e impunemente bater-lhe. Era mulata. E a rapariga comeu e continuou em pé, sem se mexer, com a mão na cara, sem nada dizer [...] Disse-lhe, já levaste, e depois afastei-me para o fundo do pátio, absolutamente consciente da infâmia que tinha cometido, esse exercício de poder que não compreendia, e com que não concordava. [...] Nada podia contra mim. Queixasse-se, e depois?! Eu era branca. (FIGUEIREDO, 2018, p. 78)

A lembrança do motivo já se apagou, "sei lá por que lhe dei a maldita bofetada" (FIGUEIREDO, 2018, p. 78), mas a infâmia da violência calcada na posição opressiva, que engendra diretamente significante racial em sua base, permanece - e atua em paralelo com a violência exercida pelo pai. É uma situação muito contundente, ainda mais se observarmos a própria "imagem de Moçambique":

Moçambique é essa imagem parada da menina ao sol, com as tranças louras impecavelmente penteadas, perante a criança negra empoeirada, quase nua, esfomeada, num silêncio em que nenhum sabe o que dizer, mirando-se do mesmo lado e dos lados opostos da justiça, do bem e do mal, da sobrevivência. (FIGUEIREDO, 2018, p. 167) 
$\mathrm{O}$ ato de rememorar presentifica a imagem. "Por exemplo, neste momento estou a olhá-los através do tempo, e há perplexidade em seus olhos, um vazio, uma fome, e nos meus uma impotência" (FIGUEIREDO, 2018, p. 167). A memória ganha a forma de uma fotografia, como a lembrança última de seus pais em Moçambique, pela janela do avião: "Congelada no espaçotempo, esta foto muito antiga, manchada de dedadas, machucada pelo uso, guardada numa gaveta para sempre intacta do meu cérebro" (FIGUEIREDO, 2018, p. 131). Apresentam-se no livro, desse modo, elementos centrais das reflexões teóricas sobre a memória, e é esse movimento que permite observar como se constrói a postura ética.

Com o avanço dos anos abre-se um abismo entre a criança e a figura do pai. Do início ao fim do livro há essa constante transição e afastamento de noções "cristalizadas", da "história oficial". Até que chegamos ao fragmento 32:

Acho que foi a última vez que estive no meio deles. Entre eles.

Nesse silêncio revi a matéria.

Era a portadora da mensagem; levava comigo a verdade. A deles.

A minha, também, mas eles não imaginariam que eu pudesse ter uma verdade só minha, sem a sombra das suas mãos.

E revi a matéria. (FIGUEIREDO, 2018, p. 122)

Nesse momento estamos no pós-25 de abril de 1974. Os pais querem que ela vá para Portugal. Estão com medo dos resultados da independência: dos massacres posteriores, mas também do novo sistema. Esse trecho é inserido em um fragmento bem contundente, que inicia com a organização para a viagem e com uma descrição seca dos próprios fundamentos dessa "verdade paterna" - que, em si, representa o discurso oficial do mito civilizatório:

Tínhamos ficado para o fim. O meu pai acreditava num reviralho, numa África branca na qual os negros haviam de se assimilar, calçar, ir à escola e trabalhar.

Os negros haviam de nos sorrir, sempre, e agradecer o que fizéramos pela sua terra, quer dizer, pela nossa terra, e servir-nos, evidentemente, porque eram negros, e nós brancos, e esta era a ordem natural das coisas. Não é normal habituar os cães a coleira e trela, ou abater um cabrito e assá-lo? Pois essa era a ordem do mundo. (FIGUEIREDO, 2018, p. 119)

No mesmo fragmento, ainda, reflete sobre o papel da Escola e de suas mudanças após a independência, o que, de modo muito sintomático, recai na disciplina de História: "Os brancos riam-se. Aquilo era história de pretos! Os pretos julgavam que tinham história! 'A história dos macacos"” (FIGUEIREDO, 2018, p. 121) - o que também desvela os processos de apagamento ao qual se submete os povos oprimidos. 
Já sem condições de permanecer, os pais a pedem que relate em Portugal os acontecimentos - exigem seu testemunho. A "verdade deles". Mas a narradora é contundente e marca de modo direto seu posicionamento ético-político em relação ao passado. Nesse processo, muitas vezes não é importante descrever o passado "tal como ele de fato foi", se o vestido era branco ou azul, se a conversa se deu no Alto Maé ou não. O que importa é o modo como a articulação desse passado se dá baseada em uma ética da ação presente. A posição da narradora-personagem, assim, é próxima a de um herói trapeiro (BENJAMIN, 2000), ou do próprio Anjo da História: ela é capaz de se deter nesse passado, de recuperar os fragmentos e restos de memória que compõem a constelação de sua identidade. Ao fazer isso resgata a história das vítimas do colonialismo, articulando-a com o presente. Essa articulação não é fortuita. É guiada por um dever de memória.

\section{O TESTEMUNHO DO REGIME COLONIAL}

Para prosseguir na leitura do Caderno, é interessante observar a formulação das teses de Benjamin em relação à dois textos anteriores: "Experiência e Pobreza" (BENJAMIN, 2012, p. 123), de 1933; e "O narrador" (BENJAMIN, 2012, p. 213), de 1936. Ambos partem de reflexões próximas, sobre as impossibilidades de se representar o horror, e atingem proposições complementares. Segundo Benjamin, em "Experiência e Pobreza", em decorrência do trauma da guerra e do avanço descontrolado da técnica, surge uma nova forma de miséria. O ser humano perde o contato com o próprio patrimônio cultural, já que a experiência do horror o desvincula dessas noções "eternas", como os "valores da pátria”. Ele perde a capacidade de comunicar o horror, o que cria um paradoxo: não é possível narrar o vivido, mas é absolutamente necessário o fazer tanto para superar o trauma, no âmbito pessoal, quanto para que o horror não se perpetue, no social e histórico. O "dever de memória” não se constrói sem sofrimentos, embates, paradoxos, incompreensões. Da discrepância entre a experiência e os modelos oficiais de cultura, resulta um necessário repensar das categorias fixas, já que as formas tradicionais são insuficientes. Essa reflexão prossegue em " $\mathrm{O}$ narrador”, que descreve o declínio das grandes narrativas e apresenta outra possibilidade: a narração a partir das ruínas, capaz de transmitir fragmentos de experiências - como ocorre no Caderno. "Tal proposição nasce de uma injunção ética e política, já assinalada pela citação de Heródoto: não deixar o passado cair no esquecimento", ressalta Gagnebin (2009, p. 53). Já em Adorno, essa postura se apresenta como um imperativo categórico: “instaurai o vosso pensamento e a vossa ação de tal modo que Auschwitz não se repita, de tal modo que nada desse gênero aconteça." (ADORNO, 2009, p. 302). Apesar da singularidade da Shoah, lança-se toda essa crítica para a análise de catástrofes históricas semelhantes, na compreensão que tais violências são as mesmas perpetradas nas colônias. 
Seligmann-Silva (2008) destaca que para um sobrevivente há a necessidade do testemunho, que se caracteriza como uma "atividade elementar" para sua vida após o trauma, um desafio de superar o isolamento e "estabelecer uma ponte" com o "outro":

Nestas situações, como nos genocídios ou nas perseguições violentas em massa de determinadas parcelas da população, a memória do trauma é sempre uma busca de compromisso entre o trabalho de memória individual e outro construído pela sociedade. (SELIGMANN-SILVA, 2008, p. 67)

O crítico descreve, nesse mesmo texto, como se articulam na experiência traumática três situações: as dificuldades do ato de narrar o trauma, de encontrar meios simbólicos para sua elaboração; a própria característica "cíclica", de sempre retorno; e o "compromisso" estabelecido pelo sobrevivente a si mesmo, que se relaciona com um paradoxal sentimento de "culpa". Nas palavras de Figueiredo: "Um desterrado é também uma estátua de culpa. E a culpa, a culpa, a culpa que deixamos crescer e enrolar-se por dentro de nós como uma trepadeira incolor, ata-nos ao silêncio, à solidão, ao insolúvel erro." (FIGUEIREDO, 2018, p. 167). Culpa isenta de matiz, mas que a impele à ressignificar sua história, imersa na guerra colonial. Mas qual guerra uma menina branca, na capital e protegida pelo sistema imperante, veria?

Sabíamos tanto sobre o que faziam as tropas como sobre a política do país. Sabíamos nada.

Não descrevo uma terra ignorando que nela havia uma guerra. Havia uma guerra, mas não era perceptível do sul; não sabíamos como tinha começado, ou para que servia exatamente. Pelo menos até o 25 de Abril, não se falou disso na minha presença. Nem se evitou falar. Havia guerra porque havia turras. Havia turras porque a natureza humana era maldosa e insatisfeita. A maldade existia em todo o lado e restava-nos lutar contra ela. Daí os soldados. (FIGUEIREDO, 2018, p. 86)

A explicação infantil permite entrever como a guerra era entendida como uma política de Estado, como algo da "ordem natural das coisas" em consonância com outros trechos. Mas ainda que negue a presença da guerra ao seu redor, ou o "conhecimento" da guerra, no fragmento seguinte, numerado 20, é inserida a personagem do "primo", também sem nome. Interessante notar como sua primeira descrição se dá com base em seu preconceito linguístico, em ácida ironia: "nunca pronunciou as três silabas muito difíceis da palavra Maputo. Ma-pu-to. As cinco de Lourenço Marques fluíam líquidas. Muito brancas." (FIGUEIREDO, 2018, p. 87). Já no fragmento 22 temos mais definições:

O meu primo tinha sido educado no mais profundo desprezo pelo negro. Quando fez dezenove anos, e o mandaram para o Niassa, partiu contente. Ia lutar pela califórnia portuguesa. [...]

Era a guerra, e o meu primo nunca falou da guerra. Ninguém falava da guerra. Suponho que não se fale da guerra, nunca. 
“Então, são tesos, os gajos, lá no Norte?” Ele sorria, não respondia. [...] O meu primo falava pouco e evitava a roda social. Fechava-se no quarto a fumar, e calou-se para sempre. Mesmo que tenha dito uma ou outra coisa depois disso, "sim, não, talvez, não sei”, nunca mais falou. Tinha vergonha [...].

O meu primo acordou o meu primeiro desejo, e, uns anos mais tarde, matou-se. (FIGUEIREDO, 2018, p. 91)

A incomunicabilidade gerada pelo trauma da guerra e a ruptura com o patrimônio cultural marcam a personagem do primo. Esse silenciamento se repete no livro na prisão do pai, após a independência de Moçambique (FIGUEIREDO, 2018, p. 158). No fragmento 21, o anterior, descreve-se sua morte de modo muito mais direto:

Tinha estado no Niassa com autorização para matar pretos, e tudo aquilo cheirava a sangue, e cheirou durante muitos anos, mesmo enterrado no chão fértil, incerto da Matola, até se oferecer um tiro nos miolos, já em Xabregas, após ter queimado todas as veias, assaltado ourivesarias na Almirante Reis e assassinado negros a tiros, pelas costas, na Damaia.

Para além disso, foi meu primo direito. (FIGUEIREDO, 2018, p. 88)

Marca-se, assim, o afastamento do discurso oficial da guerra colonial e o modo como o racismo se (re)produz na educação militarizada. A personagem do primo evidencia contraponto fundamental na composição da narradora-personagem. É, justamente, a possibilidade de transmissão simbólica da experiência vivida, de parâmetros de representação para compreendê-la, que sustenta o testemunho elaborado no Caderno. Isso já fica claro logo no início, no fragmento 4:

Os livros podiam conter sordidez, malevolência, miséria extrema, mas, a um certo ponto, havia neles uma redenção qualquer. Alguém se revoltava, lutava e morria, ou salvava-se. Os livros mostravam-me que na terra onde vivia não existia redenção alguma. Que aquele paraíso de interminável pôr-do-sol salmão e odor a caril e terra vermelha era um enorme campo de concentração de negros sem identidade, sem a propriedade de seu corpo, logo, sem existência. Nada nos meus livros, que recorde, estava escrito desta exata forma, mas foi o que li! (FIGUEIREDO, 2018, p. 46).

Dá-se a configuração de Lourenço Marques diretamente como um campo de concentração. Apresenta as questões de elaboração da memória como vimos até aqui: "Nada nos meus livros, que recorde", estava naquela "exata forma”. E insere uma relação fundamental, que é o espaço de transmissão simbólica da literatura e sua capacidade de redenção: "Um livro trazia um mundo diferente dentro do qual eu podia entrar. Um livro era uma terra justa." (FIGUEIREDO, 2018, p. 46). O ato subversivo, que é a leitura, é apontado como responsável pelo distanciamento com a figura do pai - sua traição. No fragmento 18 , sobre o dia em que se deu conta de que "sabia ler", reflete: 
Apossei-me da ferramenta com que escavaria a minha liberdade.

Foi quando, devagar, comecei a tornar-me a pior inimiga do meu pai. A inimiga lá dentro, calada. Que vê e escuta sem ter pedido autorização, porque está incluída, porque faz parte. [...]

Só muitos anos mais tarde, compreendi que saber ler, o acesso a essa chave de descodificação do segredo, me transformara, contra todas as vontades, na toupeira que lhes havia de roer todas as raízes, devagar, uma de cada vez, até restar pó" (FIGUEIREDO, 2018p. 83)

Nesse sentido, o próprio livro é um espaço de "transição", em que é possível elaborar simbolicamente essa experiência tão complexa. A necessidade deste espaço advém não apenas do posicionamento ético de Isabela Figueiredo ao compor esses fragmentos, por guiar seu testemunho em prol da memória das vítimas do colonialismo, mas também da elaboração dos traumas infligidos sobre o seu próprio corpo. Claro que a vivência nesse sistema, em si, já é traumática, inclusive pelos atos perpetrados, mas há um outro âmbito de violências que se inscreve após sua ida à Portugal. Figueiredo representa de forma muito contundente a experiência de ser uma criança retornada - mas retornar à uma terra em que nunca se esteve?

Paradoxo apenas aparente, pois é a terra de seu pai, parte do corpo de seu pai, portanto, sua terra, parte de seu corpo. Corpo que é território em guerra (FIGUEIREDO, 2018, p. 160). Que sofre duplo desterro. A fratura criada pela partida, sozinha, de Moçambique se traduz na composição dos fragmentos finais da narrativa. "Já estou aqui, contudo, ainda estou lá. Todo o passado, presente e futuro ali se fundiram, naquela viagem, e eu só posso falar usando palavras de fronteira, de transição, manchadas, duais que aí se formam" (FIGUEIREDO, 2018, p. 128). Há um constante retorno, um ir e vir, principalmente entre o fragmento 34 e o 43, entre imagens de um fim nas quais se engendram as de um começo - como uma lenta transição, em que cada resto de memória recuperada fizesse uma viagem própria, compondo a identidade fragmentada em novo solo.

A contundência com que inscreve o sistema colonial não é menos contundente na imagem de Portugal. Como ao descrever a pobreza em que vivia com sua avó - que atinge toda a metrópole e a própria imagem dos "portugueses de Portugal" (FIGUEIREDO, 2018, p. 157) -, na qual compreende também sua condição de "remediada", que difere substancialmente da pobreza dos brancos da colônia - a metrópole é fria, cinza, pálida, gélida. De seus primeiros anos como retornada, chama a atenção a insistência para que deixe de estudar - o que também desvela os antagonismos entre a situação dos portugueses na colônia e na metrópole - e as inúmeras violências que sofre: por ser mulher, por ser retornada.

O fragmento 44, em particular, rememora a violência sexual sofrida, já em 1976, trabalhando em uma pequena fábrica de louças: “O ti Gusto talvez gostasse do barro, mas do que ele gostava mesmo era de ter na garagem 
um ramalhete de meninas de peitos duros e fresquinhos, umas mimosas, de face rosada" (FIGUEIREDO, 2018, p. 155). Descreve sua tentativa de fugir do abuso: "Sentia-lhe o sexo teso, enquanto me desviava; [...] Empurrava-me contra a porta de zinco ondulado para me apalpar as mamas [...] enquanto me esgueirava, e para não o irritar, disfarçava a consciência da ameaça”" (FIGUEIREDO, 2018, p. 156). E o trauma da violência sexual traduz-se, logo no início deste mesmo fragmento, na metáfora do barro, terra que ganha forma nas louças: "As flores, umas magnólias vistosas, eram moldadas à mão, pétala a pétala, e as impressões digitais de quem as trabalhava ficavam nelas gravadas para sempre" (FIGUEIREDO, 2018, p. 154). A cicatriz do trauma, a cisão, essa mancha indelével da violência sofrida. $E$, novamente, a imagem crítica atinge toda a imagem da "metrópole": "O ti Gusto era a lamentada fina flor do drama e das virtudes provincianas" (FIGUEIREDO, 2018, p. 156). A complexidade do Caderno advém dessa sobreposição de violências que são retratadas.

\section{CONCLUSÃO}

Por fim, na tentativa de compreender uma linha entre todos esses processos paralelos do livro, pode ser interessante observar uma definição de testemunha:

Testemunha também seria aquele que não vai embora, que consegue ouvir a narração do outro e que aceita que suas palavras levem adiante, como num revezamento, a história do outro: não por culpabilidade ou por compaixão, mas porque somente a transmissão simbólica, assumida apesar e por causa do sofrimento indizível, somente essa retomada reflexiva do passado pode nos ajudar a não repeti-lo infinitamente, mas a ousar esboçar outra história, inventar o presente. (GAGNEBIN, 2009, p. 57).

Gagnebin, nesse momento, reflete sobre o sonho relatado por Primo Levi, que se repete com variações para vários sobreviventes: ao chegar em casa com os seus e contar com alívio os horrores vividos, ver que aqueles em que confiava não lhe ouvem, não acreditam. Evoca a responsabilidade dessa terceira pessoa, que não é nem a vítima nem o algoz. Nós, aqueles que ouvimos os relatos. Mas talvez possamos compreender o testemunho que se desenvolve em Caderno de memórias coloniais a partir desses três elementos, em unidade. Por culpa, movida pela recorrência do trauma, pela traição ao pai e pelas violências perpetradas, por sua posição tão próxima do algoz; e por compaixão, ao elaborar seu testemunho singular e incluir o "outro" como um dos focos de transmissão da experiência - de uma criança que vê esse sistema em operação e, quando adulta, revê sua história em postura ética. Por ambos, novamente, ao se situar nesse local de transição. E por necessidade de transmissão simbólica, já que sobre seu próprio corpo incidem uma série de violências, desterros, ausências e fraturas. Necessidade que impele a narradora-personagem - e nós, leitores - à Literatura. 
A importância do Caderno de memórias coloniais, desse modo, é dada por essa posição singular de testemunho, elaborada em uma ampla zona cinzenta: de uma "colonizadora" que se torna anticolonialista; que inflige e sofre violências diversas, com base no preconceito de raça e de classe; que é duplamente exilada, de sua terra natal, na qual era invasora, e de seu patrimônio cultural, da terra de sua família. São muitos fatores e, como vimos, não há uma verdade simples. Isso se traduz, no livro, em várias camadas significação e com diversos recursos. Complexidade exposta, da qual não se busca fugir:

Todos os lados possuem uma verdade indesmentível. Nada a fazer. Presos na certeza absoluta, nenhum admitirá a mentira que edificou para caminhar sem culpa, para conseguir dormir, acordar, comer, trabalhar. Para continuar. Há inocentes-inocentes e inocentes-culpados. Há tantas vítimas entres os inocentes-inocentes como entre os inocentes-culpados. Há vítimas-vítimas e vítimas-culpadas. Entre as vítimas há carrascos. (FIGUEIREDO, 2018, p. 136).

Deve-se deixar muito clara essa situação no livro: não se trata de equiparar vítimas e algozes. Como observamos, há uma postura direta a respeito de qual "verdade" é a relatada. Mas aponta-se, sempre, para a multiplicidade de relações, todas elas com seus efeitos. Podemos compreender isso, por exemplo, a partir de outros trechos de Levi (2016, p. 27), em que descreve a chamada "zona cinzenta". Ou de como procurou-se analisar, na confissão dos algozes, as "motivações" de seus atos, se tinham "consciência" deles. Há aqui uma necessidade de esclarecimento. Claro que há limites nesse tipo exigência iluminista, como pontua Gagnebin (2009, p.103), mas ela ainda é importante. Trata-se compreender como o algoz se torna algoz, o que no livro remete diretamente à figura do pai, mas também incide sobre si mesma, em um nível profundo, de compreender a própria identidade, de buscá-la no encontro com as cicatrizes.

Mesmo em sua parte final, o livro mantém toda a contundência. De forma até "confusa", poderíamos dizer, que é reflexo da própria fratura múltipla que a narradora-personagem nos oferece. O fragmento 45 (FIGUEIREDO, 2018, p. 45), por exemplo, é sintomático nesse sentido. Há uma oposição de discursos, entre o dos "retornados" e dos "portugueses da metrópole”, em que o próprio discurso é uma fronteira: as definições confundem-se, mesclam-se entre o que tenta construir e o oficial, que lhe é imposto. Embate constante entre a linguagem e a sua constituição interna.

Há uma desolação, um não saber essencial, que torna o fim do livro também uma ação cíclica. O primeiro fragmento do Caderno trata do nascimento. O penúltimo da morte, do abandono dos "restos do império" (FIGUEIREDO, 2018, p .169). Esse despojamento dos restos corresponde a todo o movimento do livro, a tudo aquilo que a narradora-personagem realiza, mas, no fim, ela mesmo se vê como uma ruína. O último transita entre o apagamento, com a imagem da "noite" que cai "sobre todas as coisas 
da terra", e a repetição: “e agora podes subir de novo às árvores”. E fecha-se no indefinido: "para onde vais? para onde vais agora?" (FIGUEIREDO, 2018, p. 170-171). No início e no fim do livro são inseridas duas fotos, ambas de 1960. A primeira talvez não nos diga muito, à primeira leitura, mas incide sobre a última todo o peso das memórias resgatadas, toda essa procura. Há um constante movimento pendular, entre o definido e o indefinido, que é reiterado, por fim, por outro dispositivo estético, que substitui a dedicatória ao pai das edições anteriores. Um poema, de Manuel António Pina, sobre aquilo que é resto e é falta: "a memória do esquecimento de tudo" (PINA apud FIGUEIREDO, 2018, p. 173).

\section{REFERÊNCIAS}

ADORNO, Theodor. Dialética negativa. Trad. Marco Antonio Casanova. Rio de Janeiro: Jorge Zahar, 2009.

BENJAMIN, Walter. Magia e técnica, arte e política: ensaios sobre literatura e história da cultura. Obras Escolhidas I. 8 ${ }^{\text {a }}$ ed. São Paulo: Brasiliense, 2012. A Modernidade. In: . A modernidade e os modernos. $2^{\mathrm{a}} \mathrm{ed}$. Rio de Janeiro: Tempo Brasileiro, 2000.

FIGUEIREDO, Isabela. Caderno de Memórias Coloniais. $1^{\text {a }}$ ed. São Paulo: Todavia, 2018.

. Palavras prévias. In: . Caderno de memórias coloniais. $1^{\mathrm{a}} \mathrm{ed}$. São Paulo: Todavia, 2018. p. 07-12.

. O meu corpo e o dele. In: Caderno de memórias coloniais. $1^{\text {a }}$ ed. São Paulo: Todavia, 2018. p. 175-180.

GAGNEBIN, Jeanne Marie. Lembrar escrever esquecer. 2a ed. São Paulo: Editora 34, 2009.

JORGE, Silvio Renato. As fotografias de um caderno: passeio pelas memórias coloniais de Isabela Figueiredo. Metamorfoses - Revista de Estudos Literários Luso-Afro-Brasileiros, v.13, n.2, p. 54-64, 2015. https://doi.org/10.35520/ metamorfoses.2015.v13n2a5090

LAKS, Daniel. A produção narrativa da identidade em 'Caderno de memórias coloniais', de Isabela Figueiredo. Revista Abril - Núcleo de Estudos de Literatura Portuguesa e Africana, Niterói, v. 11, n. 22, p. 63-75, jan/jun 2019. https://doi.org/10.22409/abriluff.v11i22.29983

LEVI, Primo. Os afogados e os sobreviventes. $3^{\text {a }}$ ed. Rio de Janeiro: Paz e Terra, 2016.

REIS, Carlos. Do Neo-Realismo ao Post-Modernismo. In: . História Crítica da Literatura Portuguesa. Coimbra: Editorial Verbo, 2005. 
SELIGMANN-SILVA, Márcio. Narrar o trauma: a questão dos testemunhos de catástrofes históricas. Psicologia Clínica, Rio de Janeiro, v. 20, n.1, p. 6582, agosto, 2008. https://doi.org/10.1590/S0103-56652008000100005

Recebido para avaliação em 25/03/2021

Aprovado para publicação em 07/06/2021

\section{NOTAS}

1 Mestrando em Estudos de Literatura pela Universidade Federal de São Carlos (UFSCar). Graduação em Letras - Português/Espanhol pela mesma universidade. Membro do "Núcleo de Estudos e Pesquisas sobre Poesia Contemporânea” (NEPPOC-CNPq-UFSCar). ORCID: https://orcid.org/0000-0002-0639-2995

2 A primeira edição de Caderno de memórias coloniais foi publicada em 2009. Como um trabalho em movimento, há diferenças significativas na segunda edição - que conta com oito fragmentos a mais, mudanças de fotos, frases reduzidas ou inseridas, entre outros -, que foi utilizada neste artigo.

3 É o caso da outra epígrafe do Caderno, que abrange uma dimensão íntima da traição ao pai.

4 Destaca-se que há um grande esforço de Isabela Figueredo, inclusive, em explicar essas questões diretamente. Neste artigo, nos detemos na estrutura interna de Caderno de memórias coloniais (2018), pois sua tecitura é bastante significativa, mas são vários os recursos que Figueiredo emprega em seu trabalho de rememoração. Muito disso pode ser analisado em seu blogue e mesmo no comparativo entre as diferentes edições do livro. Ainda que nosso escopo tenha se detido nos fragmentos de memórias, Silvio Renato Jorge (2015) sugere que o Caderno pode ser analisado considerando-se os paratextos, "O meu corpo e o dele" (FIGUEIREDO, 2018, p. 167) e as "Palavras Prévias" (FIGUEIREDO, 2018, p. 8), como parte integrante. 